\title{
KEPATUHAN PENGGUNAAN OBAT DAN KUALITAS HIDUP PASIEN DIABETES MELLITUS DI RUMAH SAKIT ISLAM JAKARTA
}

\author{
COMPLIANCE WITH MEDICINES AND QUALITY OF LIFE OF \\ DIABETES MELLITUS PATIENTS AT ISLAMIC HOSPITAL, \\ JAKARTA
}

\author{
Qufa Naufanesa*, Nurhasnah, Sinta Nurfadila, Nawang Wulan Ekaputri \\ Fakultas Farmasi dan Sains, Universitas Muhammadiyah Prof. Dr. Hamka Islamic Center \\ Jl.Delima II/IV, Klender Jakarta Timur. \\ *Penulis korepondensi, e-mail: Qufa17@gmail.com
}

\begin{abstract}
ABSTRAK
Kepatuhan penggunaan obat merupakan salah satu faktor keberhasilan terapi, maka kepatuhan penggunaan obat antidiabetik dianggap penting untuk mencapai kualitas hidup yang baik. Penelitian ini dilakukan untuk melihat hubungan antara kepatuhan penggunaan obat dengan kualitas hidup pasien Diabetes Mellitus (DM) di RS Islam Jakarta Cempaka Putih. Pengambilan menggunakan metode penelitian analitik korelatif dengan desain cross sectional selama 2 bulan. Intrumen yang digunakan pada penelitian ini yaitu kuisioner MMAS, EQ5D5L dan VAS yang telah tervalidasi di Indonesia serta belum banyak digunakan untuk penelitian. Data karakteristik responden tertinggi pada perempuan (68\%), kelompok umur 46-60 tahun (50\%), berpendidikan tamat SMA/sederajat (35\%), dan ibu rumah tangga (36,25\%). Hasil analisa kepatuhan pasien diketahui rendah yaitu sebesar 66 responden (41\%), responden lainnya dengan kepatuhan sedang sebesar 56 responden (35\%), dan responden dengan kepatuhan tinggi sebesar 38 responden (24\%). Antara kepatuhan penggunaan obat dan kualitas hidup pasien DM memiliki hubungan yang signifikan.
\end{abstract}

Kata kunci: kepatuhan, diabetes, kualitas hidup

\section{ABSTRACT}

Adherence to drug use is one of the factors for the success of therapy, so adherence to the use of antidiabetic drugs is considered important to achieve a good quality of life. This study was conducted to see the relationship between medication adherence and quality of life for diabetes mellitus patients at Islamic Hospital Jakarta Cempaka Putih. The study used correlative analytic research method with cross sectional design for 2 months. The instruments used in this study are the MMAS, EQ5D5L and VAS questionnaires which have been validated in Indonesia and have not been widely used for research. The highest data on the characteristics of respondents were women (68\%), the age group 46-60 years (50\%), had high school education / equivalent (35\%), and housewives (36.25\%). The results of the analysis of patient compliance were known to be low, namely 66 respondents $(41 \%)$, other respondents with moderate compliance were 56 respondents $(35 \%)$, and respondents with high compliance were 38 respondents $(24 \%)$. Between drug use adherence and quality of life of patients with diabetes mellitus has a significant relationship. 
Keywords: adherence, diabetes, quality of life

\section{PENDAHULUAN}

Diabetes Mellitus (DM) didefinisikan sebagai penyakit gangguan metabolisme yang ditandai dengan hiperglikemia maupun abnormalitas dalam metabolisme karbohidrat, lemak, dan protein serta mengakibatkan komplikasi kronis termasuk gangguan mikrovaskuler, makrovaskular, dan neuropati (Dipiro et al., 2009). Internasional Diabetic Federation (IDF) menyatakan tingkat prevalensi global penderita DM pada tahun 2014 sebesar 8,3\% di dunia. Indonesia merupakan negara yang menempati urutan ke-7 dengan penderita DM sejumlah 8,5 juta penderita setelah Cina, India dan Amerika Serikat, Brazil, Rusia \& Mexico (IDF, 2015). Sample Registration Survey tahun 2014 menunjukkan diabetes merupakan penyebab kematian terbesar nomor 3 di Indonesia dengan persentase sebesar $6,7 \%$ setelah stroke $(21,1 \%)$ dan penyakit jantung koroner (12,9\%) (Indonesia, 2017).

Tujuan pengobatan pada pasien DM yaitu untuk mencegah timbulnya komplikasi dan meningkatkan keberhasilan terapi. Keberhasilan terapi meliputi ketepatan dosis, ketepatan pemilihan obat, dan kepatuhan dalam pengobatan. Terdapat hubungan yang signifikan antara kepatuhan pengobatan terhadap kualitas hidup, jika seorang pasien patuh dalam pengobatannya maka kualitas hidup pasien tersebut akan meningkat pula, sebaliknya jika pasien kurang patuh dalam pengobatan maka akan menurunkan kualitas hidup pasien.

Hasil penelitian (Yuwindry and Wiedyaningsih, 2016) menunjukkan bahwa kepatuhan penggunaan obat pasien diabetes mellitus tipe 2 di depo farmasi rawat jalan RS PKU Muhammadiyah Surakarta berpengaruh signifikan terhadap kualitas hidup sebesar 75, 2\%. Berdasarkan dari data rekam medis Rumah Sakit Islam Cempaka Putih Jakarta, penyakit diabetes mellitus terjadi peningkatan dari tahun ke tahunnya dari data yang diambil pada tahun 2016 sampai 2018 bulan Januari sampai Februari. Pasien rawat jalan di Rumah Sakit Islam Jakarta Cempaka Putih mengalami peningkatan pada tahun 2016 sebanyak 6256 orang, tahun 2017 sebanyak 8963 orang dan tahun 2018 bulan Januari sampai Februari sebanyak 645 orang. Memperhatikan hal tersebut, maka perlu dilakukan evaluasi terhadap kepatuhan penggunaan obat dan kualitas hidup pasien DM di Rumah Sakit Islam Jakarta Cempaka Putih. 


\section{METODE PENELITIAN}

Alat dan Bahan

Subyek penelitian adalah pasien DM tipe 2 di Rumah Sakit Islam Jakarta Cempaka Putih yang memenuhi kriteria inklusi berjumlah 160 responden. Alat ukur penelitian berupa kuesioner kepatuhan penggunaan obat Morisky Medication Adherence Scale (MMAS), kuesioner kualitas hidup EQ-5D-5L(Euroqol-5 Dimention-5 Life) dan VAS (Visual Analogue Scale) serta data rekam medis pasien.

\section{Jalannya Penelitian}

Jumlah pasien DM di Rumah Sakit Islam Jakarta Cempaka Putih ialah 508 pasien dalam rentang satu bulan. Penentuan jumlah responden pada penelitian ini menggunakan rumus Slovin dengan derajat ketepatan (d) yang diinginkan 0,05 (5\%) (Sani, 2016).Tingkat kepercayaan yang digunakan adalah 95\%, maka didapatkan sebanyak 223 responden serta memenuhi kriteria inklusi dan eksklusi. Pengambilan data menggunakan desain cross sectional. Sebelum mengambil sampel, peneliti mengurus Ethical Clearence penelitian dan mengajukan izin penelitian. Pasien diberi tiga macam kuisioner.

\section{Analisis Data}

Analisa dan pengolahan data dilakukan dengan menggunakan program statistik IBM SPSS 24. Analisa data statistik meliputi dua langkah yaitu, analisa univariat dan bivariat. Analisis univariat digunakan untuk mendeskripsikan masing-masing variabel. Analisis univariat meliputi karakterisasi responden, variabel kepatuhan, dan kualitas hidup. Analisis bivariat metode Chi square digunakan untuk menghubungkan antara dua variabel, yaitu: hubungan antara jenis kelamin, usia, pekerjaan, pendidikan, lama menderita DM, terhadap kepatuhan penggunaan obat. Analisis bivariat metode Spearman digunakan untuk mengetahui hubungan antara kepatuhan penggunaan obat dengan kualitas hidup pasien. Skala data kedua variabel tersebut berupa data ordinal, maka analisis dilakukan dengan menggunakan uji non parametrik menggunakan Spearman dengan derajat kemaknaan kurang dari sama dengan 0,05 (5\%) yang berarti ada hubungan antara 2 variabel. 


\section{HASIL DAN PEMBAHASAN}

Responden diambil secara purposive sampling dengan mempertimbangkan kriteria inklusi dan eksklusi. Responden penderita DM yang digunakan sebagai responden penelitian ini yaitu pasien yang menjalani rawat jalan selama bulan April 2019-Mei 2019 di Rumah Sakit Islam Jakarta Cempaka Putih sebanyak 160 pasien. Data distribusi karakteristik pasien disajikan pada Tabel I.

Hasil penelitian memperlihatkan responden laki-laki yaitu 51 orang (32\%) dan perempuan 109 (68\%) dengan rentang usia 45-70 tahun paling banyak yaitu 80 orang (50\%). Semakin bertambahnya usia maka tingkat kepatuhan akan semakin rendah. Hal ini disebabkan fungsi fisiologis terjadi penurunan akibat penuaan (Rosyida et al., 2015). Hasil penelitian ini menunjukkan bahwa responden yang menderita DM lebih banyak diderita oleh perempuan (68\%) dibandingkan laki-laki (32\%). Menurut (Kesehatan, 2013) prevalensi perempuan lebih tinggi daripada laki-laki, hal ini dikarenakan beberapa faktor risiko menyebabkan tingginya kejadian DM pada perempuan bahwa wanita memiliki faktor resiko yang lebih besar terhadap DM daripada laki-laki, khususnya mereka yang memiliki riwayat diabetes gestasional atau riwayat melahirkan bayi dengan berat $4 \mathrm{Kg}$ atau lebih (Almasdy et al., 2015).

Tingkat pendidikan sebagian besar responden berpendidikan SMP ke atas sebanyak 81 orang $(50,63 \%)$. Responden mayoritas ibu rumah tangga sebanyak 58 orang $(36,25 \%)$ dan wirausaha sebanyak 33 orang (20,63\%). Hasil tersebut menunjukkan pasien dengan pendidikan rendah lebih banyak menderita DM. Hasil penelitian ini sesuai dengan penelitian sebelumnya dimana pendidikan rendah lebih banyak mengalami DM. Hal ini menunjukkan semakin tinggi tingkat pendidikan menaikkan kesadaran untuk pencegahan komplikasi kronis pada penderita DM tipe 2. Hal ini memberikan bukti tingkat pendidikan berpengaruh terhadap perilaku sehat dalam mencegah diabetes (Hakim, 2018). 
Tabel I. Distribusi karakteristik responden DM di rumah sakit Islam Jakarta Cempaka Putih periode bulan April 2019-Mei 2019

\begin{tabular}{lll}
\hline Karakteristik responden & Jumlah & \% \\
\hline Jenis kelamin & & \\
Laki-laki & 51 & 32 \\
perempuan & 109 & 68 \\
Usia & & \\
18-45 tahun & 6 & 3,75 \\
46-60 tahun & 80 & 50 \\
$>60$ tahun & 71 & 44,37 \\
Pendidikan & & \\
SD & 31 & 19,37 \\
SMP & 50 & 31,25 \\
SMA & 56 & 35 \\
SARJANA & 23 & 14,37 \\
Pekerjaan & & \\
Wirausaha & 33 & 20,62 \\
Ibu rumah tangga & 58 & 36,25 \\
Karyawan & 12 & 7,5 \\
Pensiunan & 22 & 13,75 \\
Pegawai & 6 & 3,75 \\
Lain-lain & 29 & 18,12 \\
Lama Mederita DM & & \\
<1 tahun & 7 & 4,37 \\
1-3 tahun & 34 & 21,25 \\
3-5 tahun & 55 & 34,37 \\
$>5$ tahun & 64 & 40 \\
\hline
\end{tabular}

Lama menderita DM paling banyak dalam rentang waktu > 5 tahun sebanyak 64 orang $(40 \%)$ dan paling sedikit dalam rentang $>1$ tahun sebanyak 7 orang (4,38\%). Durasi atau lamanya menderita DM tipe-2 ini tidak dapat menjamin bahwa waktu tersebut menggambarkan waktu yang sebenarnya mengalami DM tipe-2, hanya saja pasien baru mengetahui DM tipe-2 setelah terjadinya komplikasi dan memaksa pasien untuk datang ke rumah sakit (Lestari, 2013). Distribusi kepatuhan terapi pasien DM terlihat pada Tabel II.

Tabel II. Distribusi kepatuhan terapi pasien DM di rumah sakit Islam Jakarta Cempaka Putih periode bulan April 2019-Mei 2019 menggunakan kuesioner MMAS-8

\begin{tabular}{llll}
\hline No & Tingat Kepatuhan & Jumlah & \% \\
\hline 1 & Rendah & 66 & 41 \\
2 & Sedang & 56 & 35 \\
3 & Tinggi & 38 & 24 \\
\hline
\end{tabular}


Berdasarkan hasil penelitian diketahui bahwa responden mempunyai tingkat kepatuhan penggunaan obat yang rendah yaitu sebesar 66 responden (41\%), responden lainnya dengan kepatuhan sedang sebesar 56 resepondesn (35\%), dan responden dengan kepatuhan tinggi sebesar 38 responden (24\%). Apabila tingkat kepatuhan dalam minum obat sangat rendah maka akan menyebabkan kesehatan semakin memburuk walaupun pengobatan sudah sesuai dengan standar terapi yang ada (Rahmadani and Sari, 2018). Hasil penelitian ini serupa dengan penelitian Srikartika,dkk tahun 2016, menghasilkan responden patuh kategori tinggi dinyatakan sebanyak 19 responden $(39,6 \%)$, responden patuh sedang sebanyak 11 responden $(22,9 \%)$ dan responden yang patuh rendah sebanyak 29 reponden $(60,4 \%)$. Hal ini mungkin dilakukan secara sengaja dengan tidak meminum obat karena merasa penyakit yang diderita sudah membaik atau bertambah buruk, atau dilakukan secara tidak sengaja seperti kelalaian dalam meminum obat (Alfian and Putra, 2017). Tabel III memperlihatkan perilaku pasien dalam menggunakan obat berdasarkan MMAS-8.

Tabel III. Perilaku pasien dalam menggunakan obat berdasarkan MMAS-8

\begin{tabular}{llllll}
\hline No & Variable Kepatuhan & Ya & \% & Tidak & \% \\
\hline 1 & Lupa minum obat & 105 & 65,63 & 55 & 34,37 \\
2 & Sengaja tidak minum obat dalam 2 minggu & 85 & 54,13 & 75 & 46,87 \\
3 & Tidak minum obat karena kondisi memburuk & 37 & 23,13 & 123 & 76,87 \\
4 & Lupa membawa obat saat berpergian & 83 & 51,87 & 77 & 48,13 \\
5 & Kemarin lupa meminum obat & 52 & 32,5 & 108 & 67,5 \\
6 & Menghentikan penggunaan obat karena & 24 & 15 & 136 & 85 \\
& kondisi membaik & & & & \\
7 & Kurang nyaman dalam meminum obat & 68 & 42,5 & 92 & 57,5 \\
8 & Tingkat kesulitan mengingat penggunaan & & & & \\
& obat & & & 97,63 \\
& -Tidak pernah & 43 & 26,87 & & \\
& -Sesekali & 53 & 33,12 & & \\
& -Kadang-kadang & & & & \\
& -Biasanya & & & & \\
-Selalu/sering & & & & & \\
\hline
\end{tabular}

Pengukuran kepatuhan dalam menggunakan obat menggunakan kuisioner Morisky Medication Adherence Scale (MMAS8). Kuisioner ini sangat penting bagi tenaga kesehatan sebagai informasi dan evaluasi dalam memberikan informasi dan konseling kepada pasien untuk meningkatkan kepatuhan (Endah and Supadmi, 2016). Pada penelitian ini kuisioner diisi oleh responden dan peneliti membantu pasien untuk membacakan dan menuliskan jawaban pasien di lembar kuisioner. Hal ini dikarenakan 
untuk mencegah pengisian yang asal-asalan oleh responden. Ketidakpatuhan pasien dikarenakan lupa sebanyak 65,27\%. Hal ini termasuk ke dalam ketidakpatuhan yang tidak disengaja. Faktor pasien lupa minum obat, dikarenakan berkurangnya daya ingat seperti yang terjadi pada pasien lanjut usia. Ketidakpatuhan pasien selanjutnya dikarenakan sengaja tidak minum obat dalam 2 minggu terakhir $(54,13 \%)$ dan lupa membawa obat saat berpergian $(51,87 \%)$.

Faktor-Faktor yang Mempengaruhi Kepatuhan Penggunaan Obat

Pada penelitian ini hanya melihat faktor kepatuhan penggunaan obat dari jenis kelamin, pendidikan, pekerjaan, jumlah penggunaan obat, lama hemodialisa, lama terapi di Rumah Sakit, dan penyakit penyerta. Berdasarkan hasil analisis statistik dengan chi square menunjukkan pengaruh jenis kelamin $(\mathrm{p}=0,759)$, usia $(\mathrm{p}=0,412)$ tingkat pendidikan $(p=0,913)$ pekerjaan $(p=0,503)$, lama menderita DM $(p=0,341)$ terhadap kepatuhan dalam penelitian ini tidak signifikan $(p>0,05)$. Hal ini mempunyai arti semua variable yang digunakan dalam penelitian ini tidak mempengaruhi dalam pengobatan. Tabel IV memperlihatkan distribusi frekuensi karakteristik responden menurut kualitas hidup pasien.

Tabel IV. Distribusi frekuensi karakteristik responden menurut kualitas hidup pasien

\begin{tabular}{llcccc}
\hline No & Kualitas Hidup & \multicolumn{2}{c}{ EQ-5D-5L } & \multicolumn{2}{c}{ EQ-VAS } \\
& & Jumlah & \% & Jumlah & \% \\
\hline $\mathbf{1}$ & Rendah & 20 & 12,5 & 0 & \\
$\mathbf{2}$ & Sedang & 46 & 28,75 & 97 & 60,6 \\
$\mathbf{3}$ & Tinggi & 94 & 58,75 & 63 & 39,4 \\
\hline
\end{tabular}

Berdasarkan hasil penelitian tingkat kualitas hidup dengan EQ-5D-5L (Euroqol-5 Dimention-5 Life) dan EQ-VAS (Euroqol-Visual Analogue Scale) pada EQ-5D-5L tingkat kualitas hidup yang paling banyak adalah kualitas hidup tinggi sebanyak 94 responden $(58,75 \%)$, kualitas hidup sedang sebanyak 46 responden $(28,75 \%)$, dan kualitas hidup rendah sebanyak 20 responden (12,5\%), sedangkan pada EQ-VAS kualitas hidup paling banyak adalah kualitas hidup tinggi sebanyak 63 responden $(39,4 \%)$, kualitas hidup sedang sebanyak 97 responden (60,6\%). Pada hasil EQ-5D-5L dan EQVAS terdapat perbedaan dimana pada EQ-VAS tidak ada pasien yang memiliki kualitas hidup yang rendah. Pada EQ-VAS pasien diminta menilai sendiri kesehatannya pada hari dimana dilakukan pengambilan data sedangkan pada EQ-5D-5L pasien menilai kualitas 
hidupnya dari lima dimensi dengan lima level yang dapat dilihat pada gambar 1yang menjelaskan gambaran kualitas hidup berdasarkan kuisioner EQ-5D-5L dengan lima dimensi dan lima level.

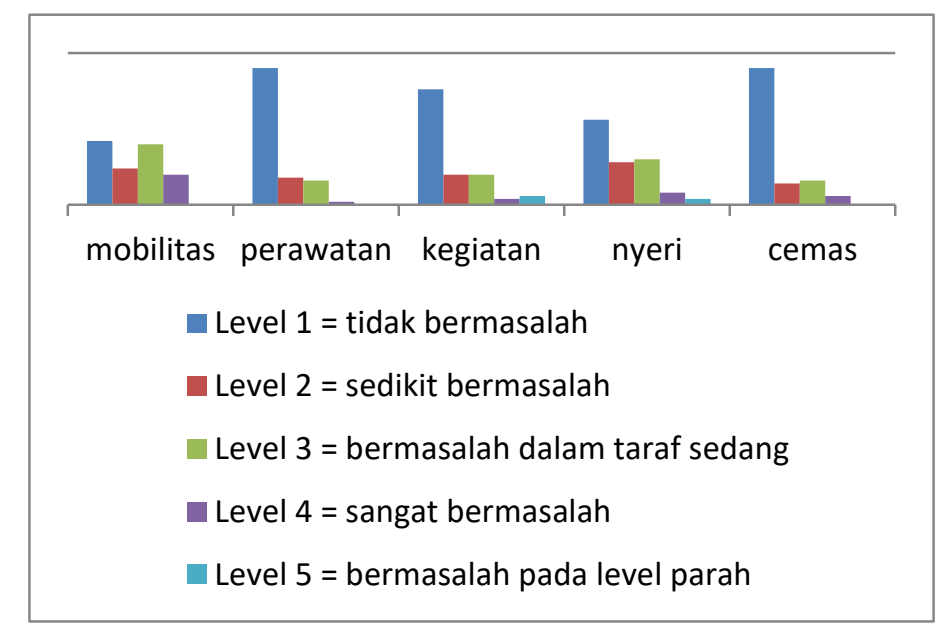

Gambar 1. Gambaran kualitas hidup pasien DM di RSIJ Cempaka Putih

Berdasarkan hasil penelitian gambaran kualitas hidup pasien DM terhadap lima dimensi EQ-5D-5L dimana paling banyak mengalami masalah pada mobilitas atau kemampuan berjalan $(70 \%)$, diikuti rasa nyeri/tidak nyaman $(58,33 \%)$, kegiatan yang biasa dilakukan $(39,68 \%)$, perawatan diri $(28,571 \%)$ dan cemas $(28,571 \%)$. Hasil penelitian ini sedikit berbeda dengan yang dilakukan oleh (Arifin et al., 2019) dengan menggunakan kuisioner yang sama EQ-5D-5L dimana pasien DM paling banyak adalah mengalami masalah pada rasa nyeri/tidak nyaman (61\%) diikuti masalah pada kemampuan berjalan (37\%), rasa cemas (34\%), kegiatan yang biasa dilakukan (34\%) dan perawatan diri (12\%). Hal tersebut dapat terjadi karena perbedaan banyaknya responden penelitian dimana pada penelitian ini 160 pasien sedangkan total responden dari penelitian (Arifin et al., 2019) berjumlah 907 pasien. Penelitian oleh (Akoit, 2015) menunjukkan semakin meningkat usia seseorang maka perawatan diri pasien diabetes semakin menurun. Hal tersebut dapat disebabkan oleh terbatasnya gerak responden karena penurunan kekuatan fisik. Tabel $\mathrm{V}$ menunjukkan faktor-faktor yang mempengaruhi kualitas hidup. 
Tabel V. Faktor-faktor yang mempengaruhi kualitas hidup

\begin{tabular}{llll}
\hline No & Faktor & $\begin{array}{l}\text { P Value } \\
\text { EQ-5D-5L }\end{array}$ & $\begin{array}{l}\text { P Value } \\
\text { EQ-VAS }\end{array}$ \\
\hline 1 & Umur & 0,000 & 0,122 \\
2 & Jenis kelamin & 0,668 & 0,977 \\
3 & Pendidikan & 0,003 & 0,759 \\
4 & Pekerjaan & 0,395 & 0,433 \\
5 & Lama menderita DM & 0,408 & 0,633 \\
\hline
\end{tabular}

Berdasarkan hasil penelitian dengan uji analisis statistik chi square diketahui bahwa faktor jenis kelamin, lama menderita dan pekerjaan tidak mempengaruhi kualitas hidup pasien baik dari EQ-5D-5L maupun EQ-VAS. Pada umur dan pendidikan terdapat perbedaan, dimana pada EQ-5D-5L mempengaruhi kualitas hidup, sedangkan pada EQVAS tidak mempengaruhi kualitas hidup pasien. Bila dibandingkan dengan hasil penelitian (Arifin et al., 2019) di pulau Jawa dan Sulawesi dengan menggunakan kuisioner EQ-5D-5L umur dan pendidikan diperoleh hasil tidak memiliki hubungan yang signifikan dengan $p$-value $>0,05$.

Hubungan Kepatuhan Penggunaan Obat dengan Kualitas Hidup pasien DM di RSIJ Cempaka Putih

Berdasarkan hasil penelitian pada analistik statistik menggunakan uji Spearman didapatkan p-value 0,001 dimana hasil tersebut memiliki nilai signifikan antara kepatuhan penggunaan obat dan kualitas hidup pasien DM. Dilihat dari kekuatan koefisien korelasi 0,309 berarti tingkat kekuatan hubungan antara kepatuhan penggunaan obat dan kualitas hidup yaitu korelasi cukup. Dari segi arah hubungannya mempunyai nilai 0,309 berarti positif sehingga hubungan kedua variabel tersebut bersifat searah, artinya jika kepatuhan penggunaan obat terus ditingkatkan maka kualitas hidupnya akan meningkat. Hasil penelitian ini sama dengan hasil penelitian (Katadi et al., 2019) dimana terdapat hubungan yang signifikan antara kepatuhan pengobatan terhadap kualitas hidup pasien $\mathrm{DM}$ tipe $2(\mathrm{P}=0,006)$, yaitu semakin tinggi kepatuhan pengobatan semakin baik pula kualitas kehidupannya. Hasil tersebut didukung oleh penelitian yang dilakukan (Hasina et al., 2014),(Perwitasari and Urbayatun, 2016), bahwa kepatuhan berpengaruh secara signifikan terhadap kualitas hidup. Semakin tinggi kepatuhan pengobatan seorang pasien DM maka kualitas hidupnya juga akan semakin baik. 
Pada EQ-VAS dengan hasil uji statistik Spearman didapatkan $p$-value $<0,05$. Hasil tersebut memiliki pengertian bahwa ada hubungan yang signifikan antara kepatuhan penggunaan obat dengan kualitas hidup pasien. Dilihat dari kekuatan koefisien korelasi 0,315 berarti tingkat kekuatan hubungan antara kepatuhan penggunaan obat dan kualitas hidup yaitu cukup, dari segi arah hubungannya nilai 0,315 berarti positif sehingga hubungan kedua variabel tersebut bersifat searah, artinya jika kepatuhan penggunaan obat terus ditingkatkan maka kualitas hidupnya akan meningkat.

\section{KESIMPULAN}

Berdasarkan hasil penelitian yang dilakukandi Rumah Sakit Islam Jakarta Cempaka Putih dengan responden sebanyak 160 pasien DM sebagian besar responden mempunyai tingkat kepatuhan penggunaan obat yang rendah yaitu sebesar 66 responden (41\%), responden lainnya dengan kepatuhan sedang sebesar 56 responden (35\%), dan responden dengan kepatuhan tinggi sebesar 38 responden (24\%). Berdasarkan hasil analistik statistik menggunakan uji Spearman didapatkan p-value 0,001 dimana hasil tersebut memiliki nilai signifikan antara kepatuhan penggunaan obat dan kualitas hidup pasien DM.

\section{UCAPAN TERIMAKASIH}

Terima kasih kami ucapkan kepada Program Studi Farmasi Universitas Muhammadiyah Prof. Dr. Hamka yang telah mendukung pendanaan dalam penelitian ini.

\section{DAFTAR PUSTAKA}

Akoit, E. E. (2015). Hubungan dukungan sosial dan perilaku perawatan diri penyandang DM Tipe 2. Kupang. Jurnal Info Kesehatan, 14(1), 953-966.

Alfian, R., \& Putra, A. M. P. (2017). Uji validitas dan reliabilitas kuesioner medication adherence report scale (MARS) terhadap pasien Diabetes Mellitus. Jurnal Ilmiah Ibnu Sina, 2(2), 176183.

Almasdy, D., Sari, D. P., Suhatri, S., Darwin, D., \& Kurniasih, N. (2015). Evaluasi penggunaan obat antidiabetik pada pasien DM Tipe-2 di suatu rumah sakit pemerintah kota Padang Sumatera Barat. Jurnal Sains Farmasi \& Klinis, 2(1), 104-110. 
Arifin, B., Idrus, L. R., Asselt, A. D. I. van, Purba, F. D., Perwitasari, D. A., Thobari, J. A., Cao, Q., Krabbe, P. F. M., \& Postma, M. J. (2019). Health-related quality of life in Indonesian type 2 Diabetes Mellitus Outpatients Measured With The Bahasa Version Of EQ-5D. Quality Of Life Research, 28(5), 1179-1190.

Dipiro, J. T., BG, W., \& Schwinghammer. (2009). Pharmacotherapy Handbook. New York: Mcgraw-Hill.

Endah, K., \& Supadmi, W. (2016). Kepatuhan penggunaan obat dan kualitas hidup pasien Hemodialisa Di RS PKU Muhammadiyah Yogyakarta periode Maret 2015. Yogyakarta. Jurnal Farmasi Sains Dan Komunitas, 13(2), 73-80.

Hakim, D. L. (2018). Hubungan tingkat sosial ekonomi : pendidikan, penghasilan, dan fasilitas dengan pencegahan komplikasi kronis pada penyandang DM Tipe 2 Di Surakarta. Universitas Muhammadiyah Surakarta.

Hasina, R., Probosuseno, \& Wiedyaningsih, C. (2014). Hubungan tingkat kepatuhan, kepuasan terapi dengan kualitas hidup pasien usia lanjut DM tipe 2. Journal of Management And Pharmacy Practice, 4(4), 251-256.

IDF. (2015). IDF Diabetes Atlas, Sixth Edition. Weblog. https://www.idf.org/Sites/Default/Files/Atlas-Poster2015en.Pdf

Indonesia, K. R. (2017). Profil kesehatan Indonesia. http://www.depkes.go.id/Resources/Download/Pusdatin/Lainlain/Datadaninformasikesehat anprofilkesehatanindonesia2016-Smallersize-Web.Pdf

Katadi, S., Andayani, T. M., \& Endarti, D. (2019). Hubungan kepatuhan pengobatan dengan Outcome klinik dan kualitas hidup pasien diabetes melitus tipe 2. JMPF, 9(1), 19-26.

Kesehatan, B. P. D. P. (2013). Riset kesehatan dasar. Departemen Kesehatan, Republik Indonesia.

Lestari, D. T. (2013). Faktor-faktor yang mempengaruhi inisiasi insulin pada pasien DM Tipe-2 di rumah sakit daerah kabupaten Kudus. Universitas Indonesia. 
Perwitasari, D. A., \& S, U. (2016). Treatment adherence and quality of life in diabetes mellitus patients in Indonesia. SAGE Open, 6(2), 1-7.

Rahmadani, M. A., \& Sari, A. (2018). Kepatuhan terhadap pengobatan pada pasien hipertensi dengan komplikasi DM di puskesmas Yogyakarta. Media Farmasi, 15(2), 105-112.

Rosyida, L., Priyandani, Y., Sulistyarini, A., \& Nita, Y. (2015). Kepatuhan pasien pada penggunaan obat antidiabetes dengan metode pill count dan MMAS-8 di puskesmas Kedurus Surabaya. Jurnal Farmasi Komunitas, 2(2), 36-41.

Sani, F. (2016). Metodologi penelitian farmasi komunitas dan eksperimental, deepublish: Yogyakarta.

Yuwindry, I., \& Chairun Wiedyaningsih, G. P. W. (2016). Pengaruh pengetahuan terhadap kualitas hidup dengan kepatuhan penggunaan obat sebagai variabael antara pada Pasien DM. Yogyakarta. Jurnal Managemen Dan Pelayanan Farmasi, 4(6), 249-254. 